\title{
Genetic Fidelity Analysis in the Micropropagated Banana Derived from Immature Primordial Male Flower Bud
}

\author{
N. Nandhakumar ${ }^{1}$, K. Soorianathasundaram ${ }^{1}$, D. Sudhakar ${ }^{2}$ and K.K. Kumar ${ }^{3} *$ \\ ${ }^{1}$ Department of Fruit Crops, Tamil Nadu Agricultural University, Coimbatore-641 003, India \\ ${ }^{2}$ Department of Plant Biotechnology, CPMB\&B, Tamil Nadu Agricultural University, \\ Coimbatore-641 003, India \\ ${ }^{3}$ Plant Breeding and Genetics Agricultural College and Research Institute, Killikulam, Tuticorin \\ District-628 252, India \\ *Corresponding author
}

\author{
A B S T R A C T
}

Keywords

Musa spp,

Micropropagation,

Somaclonal

Variation, ISSR and

Genetic Fidelity.

Article Info

Accepted:

15 March 2017

Available Online:

10 April 2017
Genetic uniformity of in vitro raised plants is a prerequisite for production of quality planting material of banana. Embryogenic cultures were induced from immature male flower buds of two important cultivars of banana, 'Rasthali' (Silk-Musa AAB) and 'Grand Naine' (Cavendish-Musa AAA). Cell suspensions were established and regenerated plants were evaluated for their genetic stability using 10 inter simple sequence repeat markers. ISSR marker produced totally 57 (Rasthali) and 64 (Grand Naine) clear, distinct and reproducible band classes resulting in a total of 1488 (Rasthali) and 1534 (Grand Naine) bands. The banding patterns for 10 primers were highly uniform and comparable to the field grown mother clone from which the cultures have been established. These results suggest that the establishment of embryogenic cell suspension cultures of banana could be an efficient system for production of genetically stable plants on a large scale as well as a biotechnological tool to support banana genetic improvement.

\section{Introduction}

Among the delicious dessert bananas, Grand Naine (Cavendish-Musa AAA), is widely grown in India due its high productivity and another cv. Rasthali (Musa AAB'Silk') is very popular owing to its delightful aroma and sweet pulp. Bananas in general are affected by numerous pest fungal and viral diseases. While both the verities viz., 'Gand Naine' and 'Rasthali' are susceptible viral diseases, 'Rasthali' is highly susceptible to Fusarium wilt caused by the fungi Fusarium oxysporunm $f$. sp. cubense. Micropropagation (plant tissue culture, PTC) has become an integral part of the banana production worldwide now as propagation by tissue culture from disease free mother plants have several advantages as the planting material do not carry systemic diseases, vigorous and are more uniform in their growth development and maturity and thus making the production practices easier leading to high productivity. While shoot tips have been used as explants in general for micropropagation of banana, the use of floral meristems for micropropagation have been also reported by earlier workers (Cote et al., 1996 and 
Ganapathi et al., 1999). Micropropagation using banana male floral meristems showed no detectable somaclonal variation and found to show less risk for possible virus contamination as compared to soil grown suckers (Resmi and Nair, 2007). Moreover, there is an opportunity to select male buds with desirable characteristics such as greater number of hands and fruits per bunch, which help to increase the efficiency of micropropagation and produce plantlets from the male buds that are normally discarded during harvesting. In normal cases, male buds serve only as food or fodder. Thus the demand for a large number of suckers of elite cultivars can be met using inflorescence tip cultures (Darvari et al., 2010; Hrahsel et al., 2014).

Micropropagation by embryogeneic cell suspension cultures is much more advantageous than conventional micropropagation by shoot tips (Strosse et al., 2003) Embryogenic cell suspensions (ECSs) are comprised of rapidly proliferating totipotent cells. These totipotent cells make the embryogenic cells serve as an ideal system for micropropagation and further amenable for genetic manipulations. The use of male floral primardia to initiate somatic embryogenesis in banana has been reported earlier (Grapin, 1995 and Ganapathi et al., 1999).

Despite the enormous benefits associated with the micropropagation technique, some inherent physiological problems leading to somaclonal variation in cultures remain a common occurrence during the process. Somaclonal variation in banana may vary from 0-70\% depending on genotype (Smith, 1988 and Vuylsteke et al., 1991). The early detection of the presence of somaclonal variants remains critical as it saves valuable time and minimizes the overall economic loss to the users of tissue-cultured planting materials (Bairu et al., 2011). The use of molecular tools especially inter simple sequence repeat (ISSR) markers has been accepted as the most reliable approach for early detection of genetic variations in regenerated plantlets. In addition, inter simple sequence repeat (ISSR) markers remains popular due to their relative simplicity, reliability, cost effectiveness and highly discriminative nature (Agarwal et al., 2008). Their use has been widely-accepted in numerous fields such as genetic diversity, phylogenetic studies, ecology and evolutionary biology (Bahulikar et al., 2004; Chandrika et al., 2010; Aruna et al., 2012). The present study reports the successful in vitro regeneration of $M$. acuminata cvs. Rasthali (AAB) and Grand Naine (AAA) derived from immature male flowers and evaluation of their genetic fidelity using ISSR markers.

\section{Materials and Methods}

\section{Plant material and growth conditions}

In the present study media composition for initiation, culturing, regenerating and rooting maintenance were altered according to the requirement and based on preliminary experiments. The detail of the media composition used in the study is furnished in table 1. Immature primordial male flowers was used as the source of explants and cultured on media to induce embryogenic callus on MA1 media. Four to six month old embrogenic calli were used to initiate and maintain cell suspensions in MA2 suspension medium according to the method described by Cote et al., 1996 with modifications. The media was changed and cultures resuspended frequently at seven to ten days interval. The ECS was transferred to MA3 medium for embryo formation and maturation with subculturing at monthly interval for three months. After three months, selected embryos 
were transferred onto germination medium (MA4) for embryo germination and further subcultured every three weeks. Regenerated shoots were then transferred to rooting medium (MA5) and allowed to develop roots and shoots. Acclimatization was done by transferring sufficiently grown plants into poly bags containing sterilized pot mixture 1:1:1 ratio of sand: red soil: FYM. Initially, the plantlets were maintained in the same culture environment, and then transferred to greenhouse for secondary hardening. The regenerated plants were successfully acclimatized and transferred to the field, the various stages of establishment of plant for somatic embryogenesis in field in figure 1.

\section{Isolation of plant genomic DNA}

DNA was isolated using CTAB method with minor modification. Leaf samples of about $0.5 \mathrm{~g}$ were weighed and transferred to a prechilled mortar and pestle. The powder was transferred to a centrifuge tube and $10 \mathrm{~mL}$ of pre-warmed $\left(65^{\circ} \mathrm{C}\right) \mathrm{CTAB}$ buffer $(2 \%$ cetyl trimethyl ammonium bromide, $100 \mathrm{mM}$ Tris$\mathrm{HCl}$, pH 8.0, $50 \mathrm{mM}$ EDTA, $2 \mathrm{M} \mathrm{NaCl}, 40$ $\mu \mathrm{L}$ Proteinase K $(20 \mathrm{mg} / \mathrm{ml}), 1 \%(\mathrm{v} / \mathrm{v}) \beta$ mercapto ethanol and 3\% PVP) were added to each sample and tubes were incubated at $65^{\circ} \mathrm{C}$ for $30 \mathrm{~min}$ with shaking for every $10 \mathrm{~min}$. After incubation, samples were kept in ice for $30 \mathrm{~min}$. The samples were then centrifuged in a bench top centrifuge at $12000 \mathrm{rpm}$ for 10 $\min \left(4^{\circ} \mathrm{C}\right)$. An equal volume of phenol: chloroform: octanol (25:24:1) v/v was added, mixed well by gentle inversions for 20 minutes and then centrifuged at $12000 \mathrm{rpm}$ for 10 minutes $\left(4^{\circ} \mathrm{C}\right)$. The supernatant was carefully decanted and transferred to a new tube and DNA was precipitated by adding of pre chilled isopropanol, mixed by gentle inversion incubated at $-80^{\circ} \mathrm{C}$ for $1 \mathrm{hr}$ followed by $10 \mathrm{~min}$ of centrifugation. Dissolved DNA was transferred to microfuge tube containing $100 \mu \mathrm{L}$ of sodium acetate and $400 \mu \mathrm{L}$ of 100
$\%$ ice cold ethanol. The tubes were mixed gently and incubated at $-20{ }^{\circ} \mathrm{C}$ for $20 \mathrm{~min}$ before centrifugation. The DNA pellet was washed using ice-cold $70 \%$ ethanol by brief vortexing and the tubes were again centrifuged at $10000 \mathrm{rpm}$ for $2 \mathrm{~min}$. The ethanol was removed using a pipette and the pellets dried under vacuum for $10 \mathrm{~min}$ before resuspending in $100 \mu \mathrm{L}$ of nuclease-free water. The total nucleic acids extracted were treated with $10 \mathrm{mg} / \mathrm{ml}$ of RNase A by incubating with $1 \mu \mathrm{l}$ of RNase $\mathrm{A}$ at $37^{\circ} \mathrm{C}$ for 1h. The RNase A reaction was terminated by incubating the mixture at $65^{\circ} \mathrm{C}$ for 10 minutes. The nucleic acids were stored at $20^{\circ} \mathrm{C}$.

\section{DNA quantification}

The yield of DNA per 0.5 gram of leaf sample extracted was measured by using Nanodrop spectrophotometer ND-1000. The purity of DNA was determined by calculating the ratio of absorbance at 260/280 and 260/230 nm. DNA concentration and purity was further tested by running the samples on $1.0 \%$ agarose gel and visualized using Syngene Gene Snap Gel Doc system.

\section{Amplification of isolated DNA using ISSR Primers}

Polymerase chain reactions for amplifications of ISSR primers were carried in $20 \mu \mathrm{l}$ reaction mixture volume containing $50 \mathrm{ng}$ of template DNA, $100 \mathrm{mM}$ dNTP mix, $0.6 \mu \mathrm{M}$ of random primers, $1 \mathrm{X}$ Taq DNA polymerase buffer containing $15 \mathrm{mM} \mathrm{MgCl} 2$ and $1.0 \mathrm{U}$ of Taq polymerase (Bangalore Genei Pvt. Ltd., Bangalore, India). PCR reaction was performed in a Thermal Cycler (Bio-Rad, C 1000 ${ }^{\mathrm{TM}}$ ) with the following conditions: $5 \mathrm{~min}$ at $94^{\circ} \mathrm{C} ; 35$ cycles of $1 \mathrm{~min}$ at $94^{\circ} \mathrm{C}, 1 \mathrm{~min}$ at $50^{\circ} \mathrm{C}, 1.5 \mathrm{~min}$ at $72^{\circ} \mathrm{C}$ and a final extension step $10 \mathrm{~min}$ at $72^{\circ} \mathrm{C}$. The amplified products were resolved by electrophoresis on a $1.0 \%(\mathrm{w} / \mathrm{v})$ agarose gels 
and the resulting fragments were scored under UV light using a gel documentation system (Syngene).

\section{Band scoring and data analysis}

Amplified DNA banding pattern generated on ISSR primers in the lanes were scored with binary values for the presence (1) or for the absence (0). All amplifications were repeated twice and only reproducible bands were scored. Matrix data were analyzed using the NTSYS Version 2.0 (Genetic Analysis in Excel) (Rohif, 1998).

\section{Results and Discussion}

\section{Genetic fidelity analysis}

In cv. Rasthali ISSR analysis, 10 anchored microsatellite primers, including di and tri nucleotide repeat motifs were tested individually to check genetic fidelity in test cultivars, where all primers generated well resolved reproducible banding profile. All 10 ISSR primers produced 62 scorable band classes, ranging from $200 \mathrm{bp}$ to $2500 \mathrm{bp}$ in size in cv. Rasthali. The number of bands for each primer varied from 4 (USB 842) to 9 (USB 807) with an average of 6.2 bands per primer (Table 2). A total of 1488 bands (numbers of plantlets analysed $\mathrm{x}$ number of band classes with all the ISSR primers) were generated, giving rise only monomorphic (USB 807, 808, 811, 818, 834, 836, 840, 841,842 and 868) pattern across all the plantlets analysed (Figure 2a).

In cv. Grand Naine totally 64 scorable band classes, ranging from $200 \mathrm{bp}$ to $2000 \mathrm{bp}$ in size were produced by 10 ISSR primer tested. The number of bands for each primer varied from 2 (USB 807) to 9 (USB 834) with an average of 6.4 bands per primer (Table 3 ). A total of 1534 bands were observed, where USB 807, 811, 836, 840, 841, 842, 868 primers produced monomorphic patterns and USB 808, 818 and 834 gave polymorphic banding patterns. Of the two types of patterns obtained, polymorphic classes ranged from $12.5 \%$ to $14.2 \%$. As a result $3.6 \%$ loci were found to be polymorphic between somaclones of cv. Grand Naine. ISSR primers produced monomorphic banding patterns of $96.3 \%$. Monomorphic and polymorphic shows in banding pattern obtained in cv. Grand Naine (Figure $2 \mathrm{~b}$ and 3 ).

Somatic embryogenesis is a complex process where the survival and growth of regenerated plants depend on the conditions of cultivation and are genotype dependent (Arnold et al., 2002). In the present study, the successful in vitro regeneration of Rasthali (Silk-Musa AAB) and Grand Naine (Cavendish-Musa AAA) plantlets were achieved using immature male flower explants. When tested for genetic fidelity using ISSR primers, it was observed that in plantletlets derived from somatic embryos of cv. Rasthali, there was no discernable variation from the mother plant, while in cv. Grand Naine very low 3.6\% loci were found to be polymorphic. Presence of negligible variation in the banding pattern of ECS derived plants in both test cultivars clearly indicates that the growth conditions involved in the study or exudation of phenolics during the culture did not induce higher variability. ISSR markers have been used in genetic fidelity test in other crops such as Chlorophytum arundinaceum (Lattoo et al., 2006), Betula pendula (Rynanen and Aronen, 2005), Prunus dulcis (Martins et al., 2005), Malus spp (Modgil et al., 2005), Pinus thunbergii (Goto et al., 1998) and Digitalis obscura (Gavidia et al., 1996).

In banana, there are reports of somaclonal variation especially in cultivars Williams (AAA) (Damasco et al., 1996; Israeli et al., 1996 Robusta (AAA), and Giant Governor (AAA) (Ray, 2006) in micropropagated plants 
using different molecular markers. In present study, it was observed that ECS derived plantlets were genetically identical to sucker derived plants especially in cv. Rastahlai although a very low per cent of variation was observed in cv. Grand Naine. This polymorphism observed by ISSR in ECS clones of cv. Grand Naine indicates the that the suspension cultures derived from cv. Grand Naine may be little sensitive and may probably due to recurrent subculturing during the different phases of somatic embryogenesis as regeneration of plantlets through ECS pathway required a long duration (nearly 12 months) in the present study. Variations observed in plantlets derived from cell suspension in cv. Grand Naine (AAA) was however negligible compared to the results obtained by Grapin (1995) who reported on $16-22 \%$ somaclonal variants among plants regenerated from a 'French Sombre' suspension, whereas all plants obtained via in vitro clonal propagation were normal. Moreover, Orton (1984) and Hartmann et al. (1989) have also reported that the time of duration of response to in vitro culture could promote somaclonal variation. While experimenting with plantains (AAB), Cronauer and Krikorian (1983) observed that the frequency of the occurrence of variants in any variety was confined to individual primary explants rather than the genotype to check any effect on plant morphology and agronomic traits. It has been reported that genetic variation in a culture line could be affected more by the genotype than by the period in culture (Smith, 1988; Vuylsteke et al., 1991; Vendrame et al., 1999). Extent of instability in Musa was found to depend on the interactions between the genotype and the tissue culture conditions by other researchers too (Vuylsteke et al., 1991; Martin et al., 2006)

Table.1 Culture media used for somatic embryogenesis of Grand Naine and Rasthali

\begin{tabular}{|c|c|c|c|}
\hline Media & Compositions & Function & Reference \\
\hline MA1 & 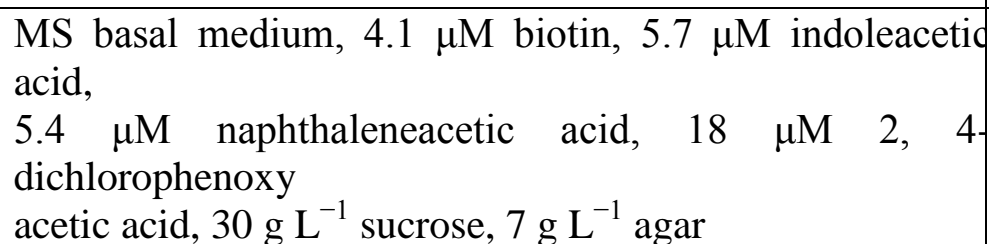 & Induction of callus & \multirow{5}{*}{$\begin{array}{l}\text { Modified } \\
\text { Cote } \text { et } \\
\text { al., } 1996\end{array}$} \\
\hline MA2 & $\begin{array}{l}\text { MS basal medium, } 4.5 \mu \mathrm{M} 2,4-\mathrm{D}, 4.1 \mu \mathrm{M} \text { biotin, } 680 \\
\mu \mathrm{M} \text { glutamine, } 30 \mathrm{~g} \mathrm{~L}^{-1} \text { sucrose }\end{array}$ & $\begin{array}{l}\text { Initiation and } \\
\text { maintenance of } \\
\text { ECS }\end{array}$ & \\
\hline MA3 & $\begin{array}{l}\text { SH basal medium supplemented with } 100 \mathrm{mg} \mathrm{L}^{-1} \text { malt } \\
\text { extraction, glutamine } 100 \mathrm{mg} \mathrm{L}^{-1}, 45 \mathrm{~g} \mathrm{~L}^{-1} \text { sucrose, } 0.2 \\
\mathrm{mg} \mathrm{L}^{-1} \mathrm{NAA}, 0.1 \mathrm{mg} \mathrm{L}^{-1} \text { kinetin, } 0.2 \mathrm{mg} \mathrm{L}^{-1} \text { zeatin and } \\
0.14 \mathrm{mg} \mathrm{L} \mathrm{m}^{-1} \text { 2- isopentyladenine and solidified in } 2 \mathrm{~g} \mathrm{~L}^{-1} \\
\text { phytagel. }\end{array}$ & $\begin{array}{l}\text { Maturation of } \\
\text { somatic embryos }\end{array}$ & \\
\hline MA4 & $\begin{array}{l}\text { MS basal medium with Morel vitamins, } 0.2 \mu \mathrm{M} 6- \\
\text { benzylaminopurine, } 1.1 \mu \mathrm{M} \text { IAA, } 30 \mathrm{~g} \mathrm{~L}^{-1} \text { sucrose, } 2 \mathrm{~g} \mathrm{~L}^{-1} \\
\text { gelrite }\end{array}$ & $\begin{array}{l}\text { Germination of } \\
\text { somatic embryos }\end{array}$ & \\
\hline MA5 & $\begin{array}{l}\text { MS basal medium, } 0.1 \% \text { activated charcoal, } \mu \mathrm{M} 6- \\
\text { benzylaminopurine, } 1.1 \mu \mathrm{M} \text { IBA, } 30 \mathrm{~g} \mathrm{~L}^{-1} \text { sucrose, } 2 \mathrm{~g} \mathrm{~L}^{-1} \\
\text { gelrite }\end{array}$ & Rooting culture & \\
\hline
\end{tabular}


Table.2 Banding pattern of ISSR marker in banana cv. Rasthali (AAB)

\begin{tabular}{|c|c|c|c|c|c|}
\hline $\begin{array}{c}\text { ISSR } \\
\text { Primers }\end{array}$ & $\begin{array}{c}\text { Primer } \\
\text { sequence }\end{array}$ & $\begin{array}{c}\text { Monomorphic } \\
\text { bands (M) }\end{array}$ & $\begin{array}{c}\text { Number of } \\
\text { scorable } \\
\text { bands per } \\
\text { primer }\end{array}$ & $\begin{array}{c}\text { Total } \\
\text { number } \\
\text { of bands } \\
\text { amplified }\end{array}$ & $\begin{array}{c}\text { Percentage } \\
\text { (M) }\end{array}$ \\
\hline USB 807 & $(\mathrm{AG})_{8} \mathrm{~T}$ & 9 & 9 & 216 & 100 \\
\hline USB 808 & $(\mathrm{AG})_{8} \mathrm{C}$ & 6 & 6 & 144 & 100 \\
\hline USB 811 & $(\mathrm{GA})_{8} \mathrm{C}$ & 6 & 6 & 144 & 100 \\
\hline USB 818 & $(\mathrm{CA})_{8} \mathrm{CG}$ & 7 & 7 & 168 & 100 \\
\hline USB 834 & $(\mathrm{AG})_{8}$ YT & 8 & 8 & 192 & 100 \\
\hline USB 836 & $(\mathrm{AG})_{8}$ YA & 5 & 5 & 120 & 100 \\
\hline USB 840 & $(\mathrm{GA})_{8}$ YT & 5 & 5 & 120 & 100 \\
\hline USB 841 & $(\mathrm{GA})_{8}$ YC & 7 & 7 & 168 & 100 \\
\hline USB 842 & $(\mathrm{GA})_{8}$ YG & 4 & 4 & 96 & 100 \\
\hline USB 868 & $(\mathrm{GAA})_{6}$ & 5 & 7 & 120 & 85.71 \\
\hline \multicolumn{2}{|c|}{ Total } & $\mathbf{6 2}$ & $\mathbf{6 2}$ & $\mathbf{1 4 8 8}$ & $\mathbf{9 4 2 . 1}$ \\
\hline \multicolumn{2}{|c|}{ Average } & $\mathbf{6 . 2}$ & $\mathbf{6 . 2}$ & $\mathbf{1 4 8 . 8}$ & $\mathbf{9 4 . 2}$ \\
\hline
\end{tabular}

Table.3 Banding pattern of ISSR marker in banana cv. Grand Naine

\begin{tabular}{|c|c|c|c|c|c|c|c|}
\hline \multirow{2}{*}{$\begin{array}{l}\text { ISSR } \\
\text { Primers }\end{array}$} & \multirow{2}{*}{$\begin{array}{c}\text { Primer } \\
\text { sequence }\end{array}$} & \multirow{2}{*}{$\begin{array}{l}\text { Monomorphic } \\
\text { bands (M) }\end{array}$} & \multirow{2}{*}{$\begin{array}{c}\text { Polymorphic } \\
\text { Bands (P) }\end{array}$} & \multirow{2}{*}{$\begin{array}{c}\text { Number } \\
\text { of } \\
\text { scorable } \\
\text { bands per } \\
\text { primer }\end{array}$} & \multirow{2}{*}{$\begin{array}{c}\text { Total } \\
\text { number of } \\
\text { bands } \\
\text { amplified }\end{array}$} & \multicolumn{2}{|c|}{ Percentage } \\
\hline & & & & & & M & $\mathbf{P}$ \\
\hline USB 807 & $(\mathrm{AG})_{8} \mathrm{~T}$ & 2 & 0 & 2 & 48 & 100 & 0 \\
\hline USB 808 & $(\mathrm{AG})_{8} \mathrm{C}$ & 6 & 1 & 7 & 168 & 85.17 & 14.28 \\
\hline USB 811 & $(\mathrm{GA})_{8} \mathrm{C}$ & 9 & 0 & 9 & 216 & 100 & 0 \\
\hline USB 818 & $(\mathrm{CA})_{8} \mathrm{CG}$ & 7 & 1 & 8 & 192 & 87.5 & 12.5 \\
\hline USB 834 & $(\mathrm{AG})_{8} \mathrm{YT}$ & 9 & 1 & 10 & 240 & 90 & 10 \\
\hline $\begin{array}{l}\text { USB } 836 \\
\end{array}$ & $(\mathrm{AG})_{8} \mathrm{YA}$ & 6 & 0 & 6 & 144 & 100 & 0 \\
\hline USB 840 & $(\mathrm{GA})_{8} \mathrm{YT}$ & 5 & 0 & 5 & 120 & 100 & 0 \\
\hline USB 841 & $(\mathrm{GA})_{8} \mathrm{YC}$ & 8 & 0 & 8 & 192 & 100 & 0 \\
\hline USB 842 & $(\mathrm{GA})_{8} \mathrm{YG}$ & 5 & 0 & 5 & 120 & 100 & 0 \\
\hline USB 868 & $(\mathrm{GAA})_{6}$ & 4 & 0 & 4 & 96 & 100 & 0 \\
\hline \multicolumn{2}{|c|}{ Total } & 61 & 3 & 64 & 1536 & 962.67 & 36.78 \\
\hline \multicolumn{2}{|c|}{ Average } & 6.1 & 0.3 & 6.4 & 153.4 & 96.26 & 3.67 \\
\hline
\end{tabular}


Fig.1 Regeneration of two Musa genotypes, A, B: Floral apex of banana; C: Ideal calli from male flower bud; D: Embryogenic mass in liquid culture medium; E: Germination of somatic embryos; F: Maturation of Somatic embryos from regeneration medium; G: Regenerated plants; $\mathrm{H}$ : Hardening of plants in the greenhouse; I: Planting in main field

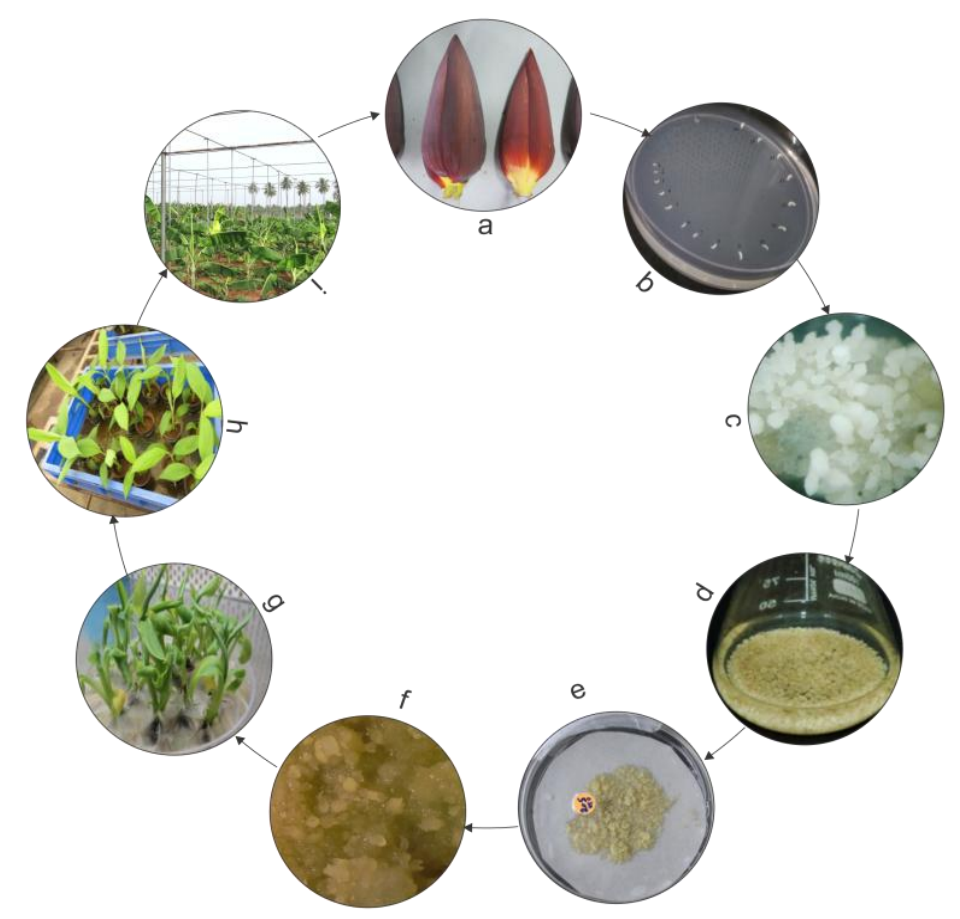

Fig.2a Genetic fidelity test in cv. Rasthali using ISSR primer (USB 811). Lane M, 1 Kb ladder; Lane M, mother plant; Lane, 2-23, ECS derived plant

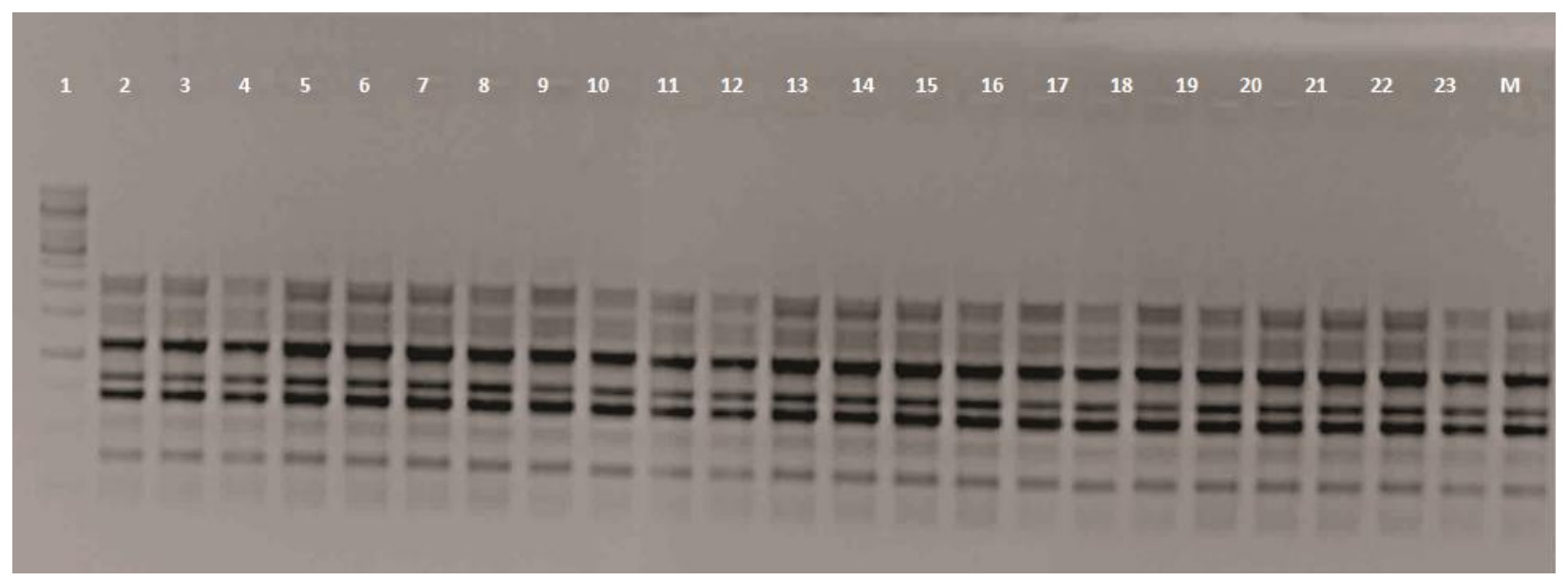


Fig.2b Genetic fidelity test in cv. Grand Naine using ISSR primer (USB 807 and USB 818). Lane 1, 1 Kb ladder; Lane M, mother plant; Lane, 2-23, ECS derived plant
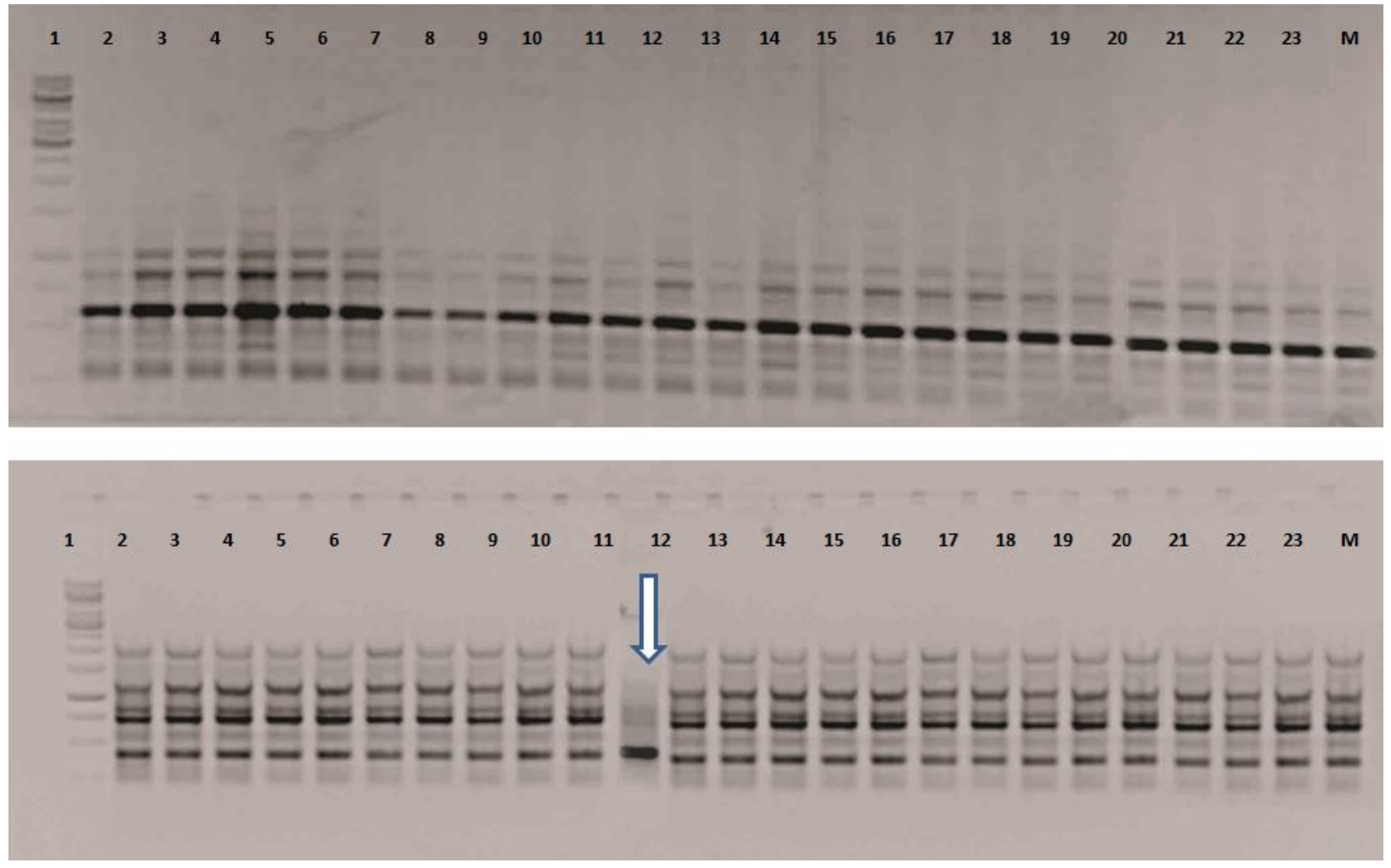

Fig.3 Dendrogram demonstrating genetic relationship among ECS derived clones of cv. Grand Naine (AAA) along with mother plant as controls based on ISSR markers

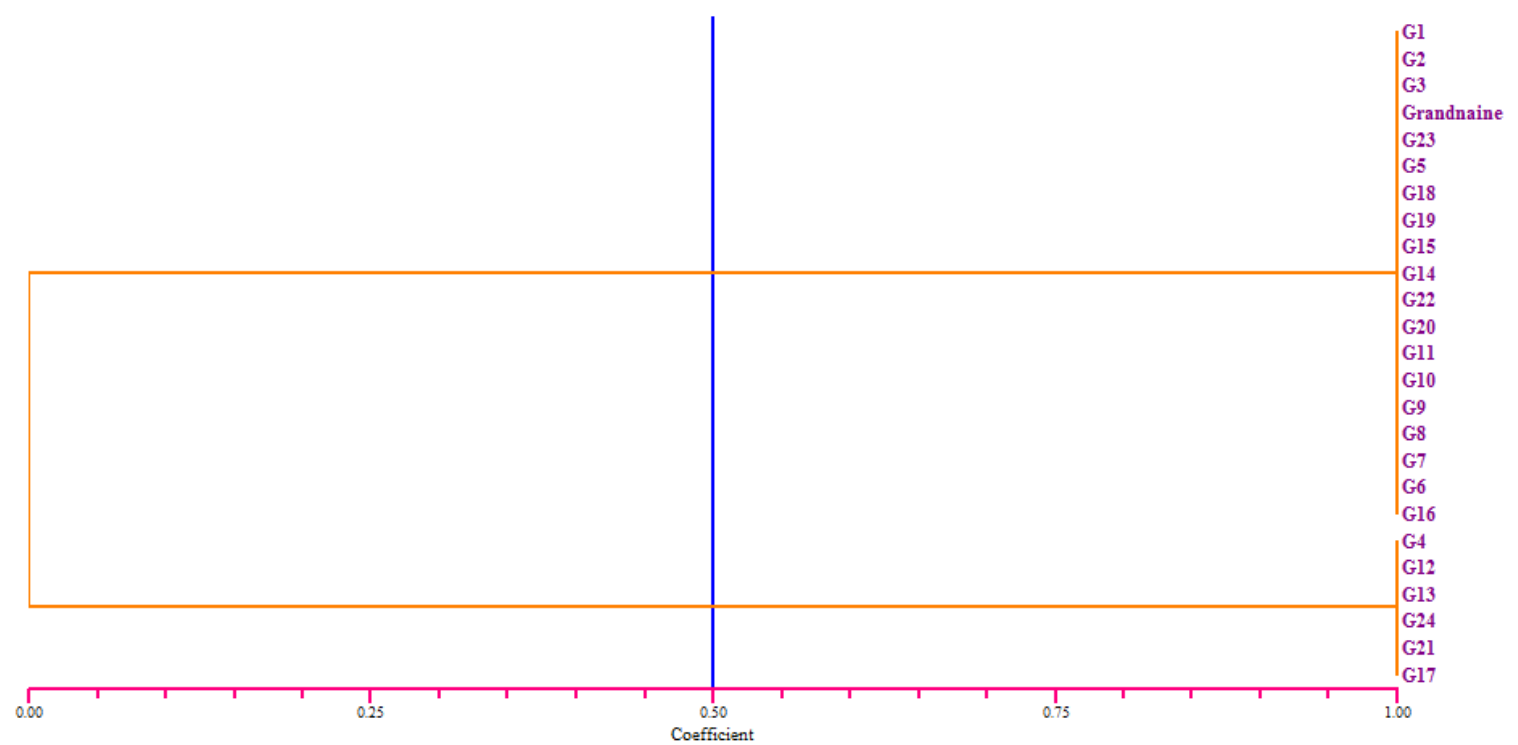

As the plantlets derived from ECS of cv. Rasthali did not show any variation in the present study with respect to the ten ISSR markers, it can be inferred that either the long duration in culture environment or the recurrent subculturing had any negative 
influence in this $\mathrm{AAB}$ genotype as compared to Grand Naine which belongs to AAA genomic group. The study clearly showed that the primordial male flower buds can serve as explants for successful micropropagation through somatic embryogenesis. Further, it is revealed that the technique being used in the experiment could very well lead to successful establishment of cv. 'Rasthali' with very little genetic variation. Among the 10 ISSR primer tested in cv. Grand Naine differential banding pattern some of the plant could be detected with primer USB818 primer, although over all polymorphism low this ISSR primer could be useful in detecting somaclonal variation in Grand Naine banana. The very low extent of polymorphism in the case of $\mathrm{cv}$. 'Grand Naine' can be attributed to the sensitivity of acuminata genome.

In conclusion, the present finding has shown that clonally identical plantlets regenerated from ECS obtained from the immature male flower bud is a cost-effective technology for generating plantlets, thus meeting the demand for large number of elite suckers. The plants regenerated in the present study were morphologically normal, suggesting normal development without somaclonal variation. There were no changes in the banding pattern observed in somatic derived plants of $\mathrm{cv}$. Rasthali and negligible variation in somatic embryos derived plants cv. Grand Naine as compared with conventional suckers of the corresponding mother plant. These results suggest that the establishment of embryogenic cell suspension cultures of banana can be effective method for production of genetically stable plants on a large scale and that the ISSR markers can be employed for testing of genetic fidelity in banana.

\section{References}

Agarwal, M., Shrivastava, N. and Padh, H. 2008. Advances in molecular marker tech-niques and their applications in plant sciences. Plant Cell Rep., 27: 617-631.

Aruna, C., Priya, A.R., Neeraja, C.N., Patil, J.V and Visarada, K.B.R.S. 2012. Diversity analysis using ISSR markers for resistance to shoot pests in sorghum. Crop Prot., 35: 110-117.

Arnold, S., Sabala, I., Bozhkov, P., Dyachok, J and Filonova, L. 2002. Developmental pathways of somatic embryogenesis. Plant Cell Tiss. Org., 69: 233-249.

Bahulikar, R., Stanculescu, D., Preston, C and Baldwin, I. 2004. ISSR and AFLP analysis of the temporal and spatial population structure of the post-fire annual, Nicotiana attenuata, in SW Utah. BMC Ecol., 4: http://dx.doi.org/10.1186/1472-6785-412.

Bairu, M.W., Aremu, A.O. and Van Staden, J., 2011. Somaclonal variation in plants: causes and detection methods. Plant Growth Regul., 63: 147-173.

Cote, F.X., Domergue, R., Monmarson, S., Schwendiman, J., Teison, $\mathrm{C}$ and Escalant, J.V. 1996. Embryogenic cell suspensions from the male flower of Musa AAA. Cv. Grand Naine. Physiol. Plant., 97: 285-290.

Cronauer, S.S and Krikorian, A.D. 1983. Somatic embryo from cultured tissue of triploid plantains (Musa, ABB). Plant Cell Rep., 2: 289-291.

Damasco, O. P., Graham,G.C., Henry, R.J., Adkins, S.W., Smith, M.K and Godwin, I.D. 1996. Random amplified polymorphic DNA (RAPD) detection of dwarf off-types in micropropagated Cavendish Musa spp. ABB group). Plant Cell Rep., 16: 118-123.

Darvari, F.M., Sariah, M., Puad, M.P and Maziah, M. 2010. Micropropagation of some Malaysian banana and plantain (Musa sp.) cultivars using male flowers. Afr. J. Biotechnol., 9: 2360-2366. 
Ganapathi, T.R., Suprasanna, P., Bapat, V.A., Kulkarni, V.M., Rao, P.S. 1999. Somatic embryogenesis and plant regeneration from male flower buds in banana. Curr. Sci. India., 76:1228-1231.

Goto, S., Thakur, R.C. and Ishii, K. 1998. Determination of genetic stability in long-term micropropagated shoots of Pinus thunbergi Parl. using RAPD markers. Plant Cell Rep., 18: 193-197.

Grapin, A. 1995. Regeneration par embryogenese somatique en milieu liquide ettransformation genetique par biolistique de bananiers di-et triploids. Ph.D.thesis, Montpellier, France, 90 pp.

Gavidia, I., Del Castillo Agudo, L and PerezBermudez, P. 1996. Selection and longterm cultures of high-yielding Digitalis obscura plants: RAPD markers for analysis of genetic stability. Plant Sci., 121: 197-205.

Hartmann, C., Henry, Y., De Buyser, J., Aubry, C and Rode, A. 1989. Identification of new mitochondrial genome organizations in wheat plants regenerated from somatic tissue cultures. Theor. Appl. Genet., 77: 169175.

Hrahsel, L., Basu, A., Sahoo, L. and Thangjam, R. 2014. In vitro propagation and assessment of the genetic fidelity of Musa acuminata (AAA) cv. vaibalhla derived from immature male flowers. Appl. Biochem. Biotech., 172: 1530 1539.

Israeli, Yair, Ben-Bassat, Dahlia and Reuveni, H. 1996. Selection of stable banana clones which do not produce dwarf somaclonal variants during in vitro culture. Sci. Horti., 67:197-205.

Kevers, C., Franck, T., Strasser, R.J., Dommes, J and Gaspar, T. 2004. Hyperhydricity of micropropagated shoots: a typically stress-induced change of physiologicalstate. Plant Cell Tiss. Org., 77: 181-191.
Lattoo, S.K., Bamotra, S., Dhar, R.S., Khan, S and Dhar, A.K. 2006. Rapid plant regeneration and analysis of genetic fidelity of invitro derived plants of Chlorophytum arundinaceum Baker-an endangered medicinal herb. Plant Cell Rep., 25(6): 499-506.

Martin, K.P., Sunandakumar, C., Chithra, M. and Madhusoodanan, P.V. 2005. Influence of auxins in direct in vitro morphogenesis of Euphorbia nivulia, a lectinaceous plant. In vitro Cell Dev Bio-Pl., 41: 314-319.

Martin, K.P., Pachathundikandi, S.K., Zhang, C.L., Slater, A and Madassery, J. 2006. RAPD analysis of a variant of banana (Musa sp.) cultivar Grande Naine and its propagation via shoot tip culture. In vitro Cell Dev. Bio-Pl., 42(2): 188-192.

Modgil, M., Mahajan, K., Chakrabarti, S.K., Sharma, D.R and Sobti, R.C. 2005. Molecular analysis of genetic stability in micropropagated apple root stock MM106. Sci. Horti., 104(2): 151-160.

Orton, T.J. 1984. Somaclonal variation: Theoritical and practical considerations, pp. 427 - 468. In: (ed. J. P. Gustafson)

Ray, T., Dutta, I., Saha, P., Das, S and Roy, S.C. 2006. Genetic stability of three economically important micropropagated banana (Musa spp.) cultivars of lower Indo-Gangetic plains, as assessed by RAPD and ISSR markers. Plant Cell Tiss. Org., 85: 1118.

Resmi, L. and Nair, A.S. 2007. Plantlet production from the male inflorescence tips of Musa acuminata cultivars from South India. Plant Cell Tiss. Org., 88: 333-338.

Rohlf. F.J. 1998. NTSYSpc numerical taxonomy and multivariate analysis system version 2.0 user guide, $37 \mathrm{pp}$. Applied Biostatistics Inc., Setauket, New York.

Rynanen, L. and Aronen, T. 2005. Genome 
fidelity during short- and long-term tissue culture and differentially cryostored meristems of silver birch (Betula pendula). Plant Cell Tiss. Org., 83: 21-32.

Smith, M.K. 1988. A review of factors influencing the genetic stability of micropropagated bananas. Fruits, 43: 219-223.

Strosse, H., Van den Houwe, I. and Panis, B. 2003. Banana cell and tissue culture reviewed. In: Jain, S.M., Swennen, R.
(Eds.), Banana Improvement: Cellular, Molecular Biology, and Induced Mutations. Science Publishers, Inc., Enfield (NH), USA, pp. 1-12.

Vuylsteke, D., R. Swennen E and De Langhe. 1991. Somaclonal variation in plantains (Musa spp. AAB group) derived from shoot-tip culture. Fruits, 46: 429439.

Vuylsteke, D.R., Crouch, J.H., Pellegrineschi, A and Thottappilly, G. 1998. The biotechnology case history for Musa. Acta Horti., 461: 75-86.

\section{How to cite this article:}

Nandhakumar, N., K. Soorianathasundaram, D. Sudhakar and Kumar, K.K. 2017. Genetic Fidelity Analysis in the Micropropagated Banana Derived from Immature Primordial Male Flower Bud. Int.J.Curr.Microbiol.App.Sci. 6(4): 1759-1769.

doi: https://doi.org/10.20546/ijcmas.2017.604.211 